\title{
Ochratoxin A in dried figs, raisings, apricots, dates on Iranian retail market
}

\author{
Ebrahim Rahimi*, Amir Shakerian \\ Department of Food Hygiene, School of Veterinary Medicine, Islamic Azad University, Shahrekord Branch, Shahrekord, Iran; \\ *Corresponding Author: ebrahimrahimi55@yahoo.com
}

Received 24 October 2013; revised 24 November 2013; accepted 9 December 2013

Copyright (C) 2013 Ebrahim Rahimi, Amir Shakerian. This is an open access article distributed under the Creative Commons Attribution License, which permits unrestricted use, distribution, and reproduction in any medium, provided the original work is properly cited.

\begin{abstract}
Ochratoxin A (OTA) is among the most important mycotoxins, and the International Agency for Research on Cancer (IARC) classifies it as possibly carcinogenic to humans (group 2B). A total of 121 samples of dried fruits from the central zone of Iran were analyzed for OTA by enzyme linked immunosorbent assay (ELISA) technique. The recovery percentages of OTA in spiked dried fruit samples at concentrations of 5,10 and 20 ng/g were found to be $84.9 \%, 89.3 \%$ and $90.4 \%$ as mean, respectively. OTA was found in $\mathbf{2 0 . 7 \%}$ of the analyzed samples by average concentration of $6.7 \pm 3.9 \mathrm{ng} / \mathrm{g}$. The incidence rates of OTA contamination in dried fig, raising, apricots, and date samples were $10.4 \%, 44.7 \%, 6.7 \%$ and $10.0 \%$, respectively. The concentrations of OTA in $7.9 \%$ of contaminated dried raising samples and $2.1 \%$ of dried fig samples were higher than maximum tolerance limit accepted by European Union (10 $\mathrm{ng} / \mathrm{g}$ ). This value reflects that the analyzed samples have a minimal contribution to toxicological risk. To our best knowledge, the present study is the first report of the presence of OTA by ELISA in dried fruit samples in Iran.
\end{abstract}

Keywords: Ochratoxin A; Dried Fruit; ELISA; Iran

\section{INTRODUCTION}

Ochratoxin A (OTA) is one of the most important mycotoxins with worldwide occurrence and toxicity, together with aflatoxins, fumonisins, trichothecenes and zearalenone [1]. This mycotoxin is produced by certain toxigenic species of Aspergillus and Penicillium. Concerning grapes, black Aspergilli (i.e. Aspergillus niger, Aspergillus carbonarius) are known as potential producers of OTA. Specifically, A. carbonarius is the most dangerous species as most $A$. carbonarius strains $(80 \%$ $90 \%$ ) display a high ochratoxigenic potential, which is mainly responsible for high toxin contamination $[2,3]$.

OTA has also been extensively documented as a contaminant of a wide variety of foods including cereals, green coffee, spices, nuts, dried fruits, beer, wine, grapes, and grape juice [4-8].

The target organ of OTA is the kidney, however, it has a wide range of other toxic effects, including hepatotoxicity, immunotoxicity, teratogenicity and neurotoxicity $[1,9]$. In humans, it has been associated with the Balkan endemic nephropathy (BEN) and with increases in the incidence of urinary tract tumors [1], but there is a lack of epidemiological evidence. Based on the aforementioned, the International Agency for Research on Cancer classified OTA as a possible human carcinogen (group 2B), supported by sufficient evidence of carcinogenicity in animal studies and inadequate evidence in humans [10]. A tolerable weekly intake (TWI) of 120 $\mathrm{ng} / \mathrm{kg}$ b.w. has also been established by the European Food Safety Authority [11].

Many countries and international organizations have regulated the OTA content in several commodities. The European commission has enforced the limits of OTA in cereals and cereal products with the following levels: 5.0 $\mathrm{ng} / \mathrm{g}$ for raw cereal grains, $3.0 \mathrm{ng} / \mathrm{g}$ for cereals and cereal products intended for human consumption, $0.5 \mathrm{ng} / \mathrm{g}$ for baby food and cereal-based food intended for young children [12]. For the dried vine fruits, soluble coffee and some dried fruits, the European commission has set a maximal permissible limit for ochratoxin A at $10.0 \mathrm{ng} / \mathrm{g}$.

Numerous methods for OTA determination in food have been described, including Enzyme-linked immunosorbent assay (ELISA) and thin layer chromatography (TLC) [7]. Liquid chromatography linked to fluorescence detection (HPLC/FD) was extensively used for OTA confirmatory analysis [13]. However, immunological 
methods are preferred to chromatographic methods in routine and survey work. In addition, enzymatic immunoassay for the detection of OTA is fairly cheap, sensitive and quick.

There is no information about the natural occurrence of OTA in foodstuffs in Iran. The aim of this survey was therefore to determine concentrations of OTA in dried figs, raisings, apricots, dates marketed in Iran.

\section{MATERIALS AND METHODS}

\subsection{Samples}

Between February 2011 and July 2011, 121 dried fruits samples including raising $(\mathrm{n}=38)$, fig $(\mathrm{n}=48)$, date $(n=20)$, and apricot $(n=15)$ were collected from supermarkets in the cities of Isfahan, Iran. Samples were stored in plastic bags at $-20^{\circ} \mathrm{C}$ until the analysis.

\subsection{Method of Analysis}

The quantitative analysis of OTA was performed using enzyme immunoassay: Ridascreen ${ }^{\circledR}$ ochratoxin A kit (RBipharm AG, Germany). The test is based on the antigen-antibody reaction. OTA extraction and tests were performed according to manufacturer's instructions. Each sample was extracted by dichloromethane with $\mathrm{NaHCO}_{3}$ buffer $(0.13 \mathrm{M}, \mathrm{pH} 8.1)$. The final extracts were diluted by distilled water and used for the specific ELISA kit. The optical density was measured at $450 \mathrm{~nm}$ using ELISA 96-well plate reader (Stat Fax 2000, England). All standard and sample solutions were analyzed in duplicate wells. The evaluation of ELISA data and the mycotoxin concentrations for samples were performed using software program (Ridasoftwin, Ridascreen ${ }^{\circledR}$ ). Recoveries were determined by spiking negative samples of analyzed food at $5 \mathrm{ng} / \mathrm{ml}$. According to the manufacturer's description, the detection limits for OTA by ELISA was $0.625 \mathrm{ng} / \mathrm{g}$.

\subsection{Statistical Analysis}

Statistical analysis of results was performed with SPSS (version 16) software (SPSS Chicago, IL, USA). The mean OTA concentration in dried fruit was compared by one way analysis of variance (ANOVA) test.

\section{RESULTS AND DISCUSSION}

The average recovery and the standard deviation (SD) obtained from spiking the blank samples with different levels of OTA (5, 10 and $20 \mathrm{ng} / \mathrm{g}$ ) for dried figs, dried raisings, dried apricots and dried dates were summarized in Table 1.

These results proved the suitabity and the effectiveness of the utilized method (ELISA) to determine different levels of OTA in dried fruits. Similar recovery rates for OTA in food (Red pepper, pistachios, sorghum, wheat, maize, barley and rice) have been reported $(85 \%$ $100 \%$ at $5 \mathrm{ng} / \mathrm{g}$ ) by Ghali et al. [7].

Results of occurrence of OTA in dried fig, raising, apricot and date samples are shown in Table 2. Five of 48 dried fig samples (10.4\%) were found contaminated with decidable levels of OTA in the range $2.3-14.2 \mathrm{ng} / \mathrm{g}$. The overall mean level of OTA in dried figs was $7.9 \mathrm{ng} / \mathrm{g}$. OTA levels in only one of the dried fig samples $(2.1 \%)$ exceeded regulatory limits applied by European regulations in dried fruits $[12,14]$. However, no maximum limit is set by the Iranian project of mycotoxin regulations for OTA in dried fruits. Although different extraction and detection techniques were used, similar incidence rate of OTA in dried figs have been reported by Bircan [15] $(18 \%$ with a maximum concentration of $24.37 \mathrm{ng} / \mathrm{g})$, and Senyuva et al. [16] from (14\% and $15 \%$; with a maximum concentration of $26 \mathrm{ng} / \mathrm{g}$ ). However, some author have reported lower incidence rates of OTA in dried figs, such as 3\% [17] and $0.1 \%-0.6 \%$ [18], whereas Guler and Heperkan [19] (48\%), Zinedine et al. [20] (65\%), Lamanaka et al. [21] (95\%) reported much higher occurrences of OTA in dried figs.

Survey for OTA in raisings have been carried out in many countries including France, Germany, Hungary, Sweden, the Netherland, Turkey, Tunisia, Canada, Finland and the UK $[22,23]$. The frequency of contamination of analyzed samples of raisings with OTA in this study was $44.7 \%$. Level of OTA in positive samples

Table 1. ELISA mean recovery rates of OTA in dried figs, dried raisings, dried apricots and dried dates.

\begin{tabular}{cccc}
\hline \multirow{2}{*}{ Samples } & \multicolumn{3}{c}{ Mean recovery $\% \pm \mathrm{SD}(\mathrm{N}=3)$} \\
\cline { 2 - 4 } & $5 \mathrm{ng} / \mathrm{g}$ & $10 \mathrm{ng} / \mathrm{g}$ & $20 \mathrm{ng} / \mathrm{g}$ \\
\hline Dried figs & $96 \pm 2$ & $90.7 \pm 1.5$ & $92.3 \pm 1.5$ \\
Dried raisings & $87.3 \pm 1.5$ & $91.3 \pm 1.5$ & $90 \pm 1$ \\
Dried apricots & $80 \pm 1$ & $87.3 \pm 0.6$ & $88.7 \pm 1.5$ \\
Dried dates & $84.3 \pm 1.5$ & $88 \pm 1.7$ & $960.7 \pm 2.1$ \\
Total & $84.9 \pm 3.5$ & $89.3 \pm 2.1$ & $90.4 \pm 3.5$ \\
\hline
\end{tabular}

Table 2. Occurrence of ochratoxin A in dried fig, raising, apricot and date samples in Iran.

\begin{tabular}{ccccc}
\hline Dried fruit & No of samples & $\begin{array}{c}\text { No of positive } \\
\text { samples }\end{array}$ & Mean \pm SD & Range \\
\hline Figs & 48 & $5(10.4 \%)$ & $7.9 \pm 4.3$ & $2.3-14.2$ \\
Raisings & 38 & $17(44.7 \%)$ & $7.0 \pm 3.8$ & $2.9-18.2$ \\
Apricots & 15 & $1(6.7 \%)$ & $2.8 \pm 0.0$ & - \\
Dates & 20 & $2(10.0 \%)$ & $2.5 \pm 1.6$ & $1.4-3.6$ \\
Total & 121 & $25(20.7 \%)$ & $6.7 \pm 3.9$ & $1.4-18.2$ \\
\hline
\end{tabular}


ranged between 2.9 - $18.2 \mathrm{ng} / \mathrm{g}$. The overall mean level of OTA in raising samples was $7.0 \mathrm{ng} / \mathrm{g}$. Although the mean concentration of OTA in raising samples was lower than the maximum tolerance accepted by some European countries (10 ng/g), but 3 samples (7.9\%) had higher concentrations than $10 \mathrm{ng} / \mathrm{g}$. These findings are in agreement with some of previous studies in Argentina [24]. Although a lower occurrence rate was reported by Zinedin et al. [20] (30\%), and Imperato et al. [25] high incidence rate of OTA in raising were more frequently observed in raisins analyzed in Germany [26], Sweden [27], Canada [28], Egypt [29] and Turkey [15,30].

Only one of the 15 dried apricot and two of the 20 dried date samples was contaminated with OTA at the 2.8 and $2.5 \mathrm{ng} / \mathrm{g}$ Level (Table 2), which was below the maximum tolerance accepted by the European Commission $(10 \mathrm{ng} / \mathrm{g})$ [12]. This low or no incidence of OTA contamination in apricots has been observed in other studies as well. Aksoy et al. [30] and Lamanaka et al. [21] did not detect any fungal growth or OTA contamination in apricot samples, claiming that application of a sulfur dioxide treatment prevented fungal contamination. In Turkey, Bircan [15] reported the occurrence of OTA in only $5 \%$ of dried apricot samples with a value of 0.97 $\mathrm{ng} / \mathrm{g}$.

Variation in the concentration of OTA, in dried fruit samples reported in other studies may be a result of different sampling techniques employed, seasonal effects and/or laboratory methodologies employed in different studies (ELISA, TLC, and HPLC). Differences in OTA levels, probably due to different weather conditions, were also reported by Pietri et al. [31] and Lopez de Cerain et al. [32], Battilani et al. [33] between samples collected in the same regions but in different years.

In Iran, traditional techniques for the transformation and conservation of fruits are still used. These practices are very optimal conditions for mould growth and mycotoxin production. The natural drying, which may consists in direct exposition of the fruit to the sun, is widely used especially in rural area in Iran. During the process of fruit drying, the sugar is concentrated as the moisture content decreases resulting in an almost selective medium for xerotolerant moulds such as $A$. niger section nigri species [20]. Among black aspergilli, A. carbonarius is the most important as OTA producing isolate observed more frequently [34]. Other black aspergilli including the A. niger aggregate, A. aculeatus and A. tubingensis have also been found to produce OTA on grapes $[2,33]$.

\section{CONCLUSION}

Based on the data exposed in this paper, the analysed samples have a minimal contribution to toxicological risk. However, it is important to inspect and control dried fruit products for the presence of OTA in a regular manner to evaluate the hygienic managements. This is the first report on the occurrence of OTA in dried fruits available in Iran. A survey of a large number of prepared food samples during these periods needs to be investigated.

\section{REFERENCES}

[1] Pfohl-Leszkowicz, A. and Manderville, R.A. (2007) Ochratoxin A: an overview on toxicity and carcinogenicity in animals and humans. Molecular Nutrition and Food Research, 51, 61-99.

http://dx.doi.org/10.1002/mnfr.200600137

[2] Medina, C., Mateo, R., López-Ocană, L., Valle-Algarra, F.M. and Jiménez, M. (2005) Study on Spanish grape mycobiota and ochratoxin A production by isolates of Aspergillus tubingensis and other members of Aspergillus section Nigri. Applied and Environmental Microbiology, 71, 4696-4702.

http://dx.doi.org/10.1128/AEM.71.8.4696-4702.2005

[3] Perrone, G., Mulè, G., Susca, A., Battilani, P., Pietri, A. and Logrieco, A. (2006) Ochratoxin A production and amplified fragment length polymorphism analysis of Aspergillus carbonarius, Aspergillus tubingensis, and Aspergillus niger strains isolated from grapes in Italy. Applied and Environmental Microbiology, 72, 680-685. http://dx.doi.org/10.1128/AEM.72.1.680-685.2006

[4] Bellí, N., Ramos, A.J., Coronas, I., Sanchis, V. and Marín, S. (2005) Aspergillus carbonarius growth and ochratoxin A production on a synthetic grape medium in relation to environmental factors. Journal of Applied Microbiology, 98, 839-844. http://dx.doi.org/10.1111/j.1365-2672.2004.02469.x

[5] Pardo, E., Sanchis, V., Ramos, A.J. and Marin, S. (2006) Non-specificity of nutritional substrate for ochratoxin A production by isolates of Aspergillus ochraceus. Food Microbiology, 23, 351-358. http://dx.doi.org/10.1016/j.fm.2005.05.005

[6] Goryacheva, I.Y., De Saeger, S., Lobeau, M., Eremin, S.A., Barna-Vetro, I. and Van P.C. (2006) Approach for ochratoxin A fast screening in spices using clean-up tandem immunoassay columns with confirmation by high performance liquid chromatography-tandem mass spectrometry (HPLC-MS/MS). Analytica Chimica Acta, 577, 38-45. http://dx.doi.org/10.1016/j.aca.2006.06.033

[7] Ghali, R., Hmaissia-khlifa, K., Ghorbel, H., Maaroufi, K. and Hedili, A. (2008) Incidence of aflatoxins, ochratoxin $\mathrm{A}$ and zearalenone in Tunisian foods. Food Control, 19, 921-924. http://dx.doi.org/10.1016/j.foodcont.2007.09.003

[8] Peraica, M., Flajs, D., Domijan, A.M., Ivić, D. and Cvjetković, B. (2010) Ochratoxin A Contamination of Food from Croatia. Toxins, 2, 2098-2105. http://dx.doi.org/10.3390/toxins2082098

[9] Sava, V., Reunova, O., Velasquez, A., Harbison, R. and Sanchez-Ramos, J. (2006) Acute neurotoxic effects of the fungal metabolite ochratoxin-A. Neurotoxicology, 27, 8292. http://dx.doi.org/10.1016/j.neuro.2005.07.004 
[10] International Agency for Research on Cancer (1993) Some naturally occurring substances: Food items and constituents, heterocyclic aromatic amines and mycotoxins. Monographs on the Evaluation of Carcinogenic Risks to Humans, 56, 489-521.

[11] EFSA (European Food Safety Authority) (2006) Opinion of the scientific panel on contaminants in the food chain on a request from the commission related to ochratoxin A in food. Adopted on 4 April 2006. The European Food Safety Authority Journal, 365, 1-56.

[12] European Commission Regulation (2006) Setting maximum levels for certain contaminants in foodstuffs. No. $1881 / 2006$ of 19 December 2006. Official Journal of the European Union, 364, 5-24.

[13] Ghali R., Hmaissia-khlifa K., Ghorbel H., Maaroufi K. and Hedili A. (2009) HPLC determination of ochratoxin A in high consumption Tunisian foods. Food Control, 20, 716-720.

http://dx.doi.org/10.1016/j.foodcont.2008.09.004

[14] Food and Agriculture Organization (2004) Worldwide regulations for mycotoxins in food and feed in 2003. FAO Food and Nutrition Paper $\mathrm{N}^{\circ}$. 81. Rome. FAO.

[15] Bircan, C. (2009) Incidence of ochratoxin A in dried fruits and co-occurrence with aflatoxins in dried figs. Food and Chemical Toxicology, 47, 1996-2001. http://dx.doi.org/10.1016/j.fct.2009.05.008

[16] Senyuva, H.Z., Gilbert, J., Ozcan, S. and Ulken, U. (2005) Survey for co-occurrence of ochratoxin A and aflatoxin B1 in dried figs in Turkey by using a single laboratoryvalidated alkaline extraction method for ochratoxin A. Journal of Food Protection, 68, 1512-1515.

[17] Ozay, G. and Alperden, F. (1991) Aflatoxin and ochratoxin A contamination of dried figs (Ficus carina L) form the 1988 crop. Mycotoxin Research, 7, 85-91. http://dx.doi.org/10.1007/BF03192171

[18] Bayman, P., Baker, J.L., Doster, M.A., Michailides, T.J. and Mahoney, N.E. (2002) Ochratoxin production by the Aspergillus ochraceus group and Aspergillus alliaceus. Applied and Environmental Microbiology, 68, 2326-2329. http://dx.doi.org/10.1128/AEM.68.5.2326-2329.2002

[19] Guler, F.K. and Heperkan, D. (2008) Natural occurrence of ochratoxin A in dried figs. Analytica Chimica Acta, 617, 32-36. http://dx.doi.org/10.1016/j.aca.2008.01.009

[20] Zinedine, A., Soriano, J.M., Juan, C., Mojemmi, B., Molto, J.C., Bouklouze, A., Cherrah, Y., Idrissi, L., E1 Aouad, R. and Manes, J. (2007). Incidence of ochratoxin $A$ in rice and dried fruits from Rabat and Sale area, Morocco. Food Additives and Contaminants, 24, 285-291. http://dx.doi.org/10.1080/02652030600967230

[21] Lamanaka, B.T., Taniwaki, M.H., Menezes, H.C., Vicente, E. and Fungaro, M.H.P. (2005) Incidence of toxigenic fungi and ochratoxin A in dried fruits sold in Brazil. Food Additives and Contaminants, 22, 1258-1263. http://dx.doi.org/10.1080/02652030500260447

[22] Varga, J., Kocsube, S., Koncz, Z. and Teren, J. (2006) Mycobiota and ochratoxin Ain raisins purchased in Hun- gary. Acta Alimentaria, 35, 289-294. http://dx.doi.org/10.1556/AAlim.35.2006.3.6

[23] Trucksess, M.W. and Scott, P.M. (2008) Mycotoxins in botanicals and dried fruits: A review. Food Additives and Contaminants, 25, 181-192. http://dx.doi.org/10.1080/02652030701567459

[24] Magnoli, C., Astoreca, A., Ponsone, L., Combina, M., Palacio, G., Rosa, C.A. and Dalcero, A.M. (2004) Survey of mycoflora and ochratoxin A in dried vine fruits from Argentina markets. Letters in Applied Microbiology, 39, 326-331.

http://dx.doi.org/10.1111/j.1472-765X.2004.01583.x

[25] Imperato, R., Campone, L., Piccinelli, A.L., Veneziano, A. and Rastrelli, L. (2011) Survey of aflatoxins and ochratoxin a contamination in food products imported in Italy. Food Control, 22, 1905-1910. http://dx.doi.org/10.1016/j.foodcont.2011.05.002

[26] Engel, G. (2000) Ochratoxin A in sweets, oil seeds and dairy products. Archive für Lebensmittelhygiene, 51, 98101.

[27] Mouller, T. E., Nyberg, M. (2003) Ochratoxin A in raisins and currants: Basic extraction procedure used in two small marketing surveys of the occurrence and control of the heterogeneity of the toxins in samples. Food Additives and Contaminants, 20, 1072-1076. http://dx.doi.org/10.1080/02652030310001615212

[28] Lombaert, G.A., Pellaers, P., Neumann, G., Kitchen, D., Huzel, V., Trelka, R., Kotello, S. and Scott, P.M. (2004) Ochratoxin A in dried vine fruits on the Canadian retail market. Food Additives and Contaminants, 21, 578-585. http://dx.doi.org/10.1080/02652030410001687681

[29] Youssef, M.S., Abo-Dahab, N.F. and Abou-Seidah, A.A. (2000) Mycobiota and mycotoxin contamination of dried raisins in Egypt. African Journal of Mycology and Biotechnology, 8, 69-86.

[30] Aksoy, U., Dunbay, O. and Gulseri, O. (1995) Survey of aflatoxins and ochratoxin A in Turkish dried apricots. ISHS Acta Horticulturae, 384, 651-654.

[31] Pietri, A., Bertuzzi, T., Pallaroni, L. and Piva, G. (2001) Occurrence of ochratoxin A in Italian wines. Food Additives and Contaminants, 18, 647-654.

[32] Lopez de Cerain, A., Gonzáles-Peñas, E., Jiménez, A.M. and Bello, J. (2002) Contribution to the study of ochratoxin A in Spanish wines. Food Additives and Contaminants, 19, 1058-1064.

http://dx.doi.org/10.1080/02652030210145928

[33] Battilani, P., Giorni, P., Bertuzzi, T., Formenti, S. and Pietri, A. (2006) Black aspergilli and ochratoxin A in grapes in Italy. International Journal of Food Microbiology, 111, S53-S60.

http://dx.doi.org/10.1016/j.ijfoodmicro.2006.03.006

[34] Sage, L., Krivobok, S., Delbos, E., Seigle-Murandi, F. and Creppy, E.E. (2002) Fungal flora and ochratoxin A production in grapes and musts from France. Journal of Agricultural and Food Chemistry, 50, 1306-1311. http://dx.doi.org/10.1021/jf011015z 